\title{
Early Assessment and Preventing the Onset of Obesity and Overweight
}

\author{
Desika $\mathbf{R}^{1}$, Rajajeyakumar $\mathbf{M}^{1}{ }^{*}$, Swetha ${ }^{1}$, Elanthamizhalan ${ }^{1}$, \\ Karthikeyan ${ }^{1}$, Akshara ${ }^{1}$ and Naganiveditha ${ }^{1}$ \\ ${ }^{* 1}$ Department of Physiology, Chennai Medical College Hospital \& Research Centre, Irungalur, Trichy, India
}

Received: 30 May, 2017; Accepted: 01 June, 2017; Published: 05 June, 2017

*Corresponding author: M Rajajeyakumar, MBBS, MD (JIPMER), MSc Yoga, CCEBDM (PHFI), FIME, (PhD). Assistant Professor, Department of Physiology, Chennai Medical College Hospital \& Research Centre (SRM Group), Irungalur, Trichy, Tamilnadu, India, Tel: 09751382650; E-mail: rajakumar60@ gmail.com or dr_rajaphysiologist88@yahoo.com

\section{Introduction}

One of the most common problems related to lifestyle today is being overweight. Obesity and overweight are serious problems that constitute an enormous and growing financial load on national resources. However, the conditions are mostly preventable through early lifestyle modification [1]. Anthropometric measurements to find out the type of overweight and obesity.

Different weight classes were defined based on Body Mass Index (BMI) as follows:

Healthy weight: $18.5-24.9 \mathrm{~kg} / \mathrm{m} 2$

Overweight: $25-29.9 \mathrm{~kg} / \mathrm{m} 2$

Obesity I: $30-34.9 \mathrm{~kg} / \mathrm{m} 2$

II: $35-39.9 \mathrm{~kg} / \mathrm{m} 2$

III: $40 \mathrm{~kg} / \mathrm{m} 2$ or more.

The use of lower BMI degree $(23 \mathrm{~kg} / \mathrm{m} 2$ to indicate increased risk and $27.5 \mathrm{~kg} / \mathrm{m} 2$ to indicate high risk) to ameliorate the risk of conditions such as type 2 diabetes, has been recommended for black African, African-Caribbean and Asian groups.

Basal measurement of the obesity risks in adults on waist circumference as follows, for men, waist circumference of less than $94 \mathrm{~cm}$ is low, $94-102 \mathrm{~cm}$ is high and more than $102 \mathrm{~cm}$ is very high. For women, waist circumference of less than $80 \mathrm{~cm}$ is low, $80-88 \mathrm{~cm}$ is high and more than $88 \mathrm{~cm}$ is very high.

Large scale consumption of energy-dense, nutrient less foods combined with decreased physical activity cause it to be an epidemic in developing countries. In 1995, the Emerging Market Economies had the highest number of diabetics. If current trends continue, India and the Middle Eastern crescent will have taken over by 2025. Increase the prevalence would also be noted in China, Latin America, the Caribbean, and Asia [2].

\section{Assessment of the Person}

Eating behaviour any comorbidities (for example type 2 diabetes, hypertension, cardiovascular disease, osteoarthritis, dyslipidemia and sleep apnea) any associated risk factors were assessed using lipid profile, blood pressure measurement (diet and physical activity) any psychosocial distress, environmental, social and family history of overweight and obesity and comorbidities.

\section{Key to have a Healthy Life}

\section{Management}

Management of overweight and obesity is multidisciplinary approach. It Include the following strategies for adults behavioral interventions like, self-monitoring of behaviour and progress stimulus control, goal setting, slowing rate of eating, ensuring social support, problem solving, assertiveness cognitive restructuring (modifying thoughts), reinforcement of changes, relapse prevention strategies for dealing with weight regain.

The main requirement of a dietary approach to weight loss is that total energy intake should be less than energy expenditure. Diets that have a $600 \mathrm{kcal} /$ day deficit. Consider lowcalorie diets (800-1600 kcal/ day). Encourage adults to increase their level of physical activity at least 30 minutes of moderate or greater intensity physical activity on 5 or more days a week. The activity can be in 1 session or several sessions lasting $10 \mathrm{~min}$ utes or more. Consider drug treatment for people who have not reached their target weight loss or have reached a plateau on dietary, activity and behavioral changes.

Bariatric surgery is a treatment option for people with obesity if all of the following criteria are fulfilled: They have a BMI of $40 \mathrm{~kg} / \mathrm{m} 2$ or more, or between $35 \mathrm{~kg} / \mathrm{m} 2$ and $40 \mathrm{~kg} / \mathrm{m} 2$ and other significant disease [3].

\section{Recommendation}

Combining exercise and diet offers more flexibility for weight loss. Exercise facilitates fat mobilization from adipose depots and fat catabolism. Preserves fat free body mass, blunts decrease in basal metabolic rate, and improves insulin activity. Ex- 
ercise stimulates fatty acid mobilization through hormones and enzyme action that target fat depots throughout the body [4,5]. Complementary and alternative therapy (YOGA) is also useful to prevent the risk of obesity and reduce the complications [6].

\section{References}

1. Lean ME. Pathophysiology of obesity. Proceedings of the Nutrition Society. Proc Nutr Soc. 2000;59(3):331-336.

2. King H, Aubert RE, Herman WH. Global burden of diabetes, 1995 -2025: prevalence, numerical estimates, and projections. Diabetes Care. 1998;21(9):1414-1431.
3. Obesity: identification, assessment and management. Clinical guideline. 2014.

4. William D. McArdle, Frank I. Katch, Victor L. Katch. Essentials of Exercise Physiology 2nd ed. Image Collection. Lippincott Williams \& Wilkins. 2000;475.

5. L. Smith Plowman, Sharon A and Denise. Digital Image Archive for Exercise Physiology. Allyn \& Bacon. 1998.

6. Rajajeyakumar M. Effect of yoga type of breathing on RR interval variability and sympatho-vagal balance early interventions to prevent the future risk of obesity related complications. J Obes Weight Loss Ther. 2015; 5:47. 